DOI: https://doi.org/10.32838/2523-4803/69-5-19

УДК 339.564/339.727.3

\title{
Войцешин В.П.
}

аспірант кафедри податків та фіскальної політики,

Тернопільський національний економічний університет

Voitseshyn Vasyl

Ternopil National Economic University

\section{КРЕДИТУВАННЯ ЕКСПОРТУ ЯК ЗАСІБ ЙОГО ФУНКЦІОНУВАННЯ}

У статті розглянуто особливості кредитування експорту в деяких краӥнах світу. Визначено, щуо воно спрямоване безпосередньо на стимулювання його розвитку щодо як забезпечення обігу продукuіï, так і коштів від ї̈ продажу. Досліджено, шзо кредитування експорту опосередковано не тільки державною підтримкою, але й підприємницькою діяльністю. Відображено, щзо порядок надання експортних кредитів супроводжується їх гарантуванням і страхуванням через оцінювання ризиків втрат політичного та комериійного характеру за певну плату на основі правил Організації економічного співробітництва і розвитку. Аналітично проілюстровано наявну залежність кредитування експорту від його вартості. Очінено можливі подальші перспективи розвитку надання експортних кредитів в Україні на основі врахування досвіду й оцінювання економічної кон'юнктури.

Ключові слова: експорт, експортні гарантії, експортні кредити, експортно-кредитне агентство, страхування експорту.

Постановка проблеми. В період кризових явищ та зростання значення експорту в господарстві країн світу необхідною умовою його перебігу є кредитування. Як форма прямого фінансування експорту надання експортних кредитів доповнює державну підтримку, яка опосередковується видатками бюджетів. Відповідно, кредитування експорту стає визначальним під час експорту, адже воно підтримує обіг проданої продукції, тобто товарів та послуг, а також коштів за неї. Крім того, надання кредитів передбачає певну плату за них та потребує забезпечення, що стає перешкодою для його повноцінного функціонування, зокрема в Україні. Саме тому сьогодні важливо проаналізувати доцільність експортного кредитування у світі та оцінити можливість його повноцінного розвитку в державах, де воно не запроваджене або діє на початковій стадії.

Аналіз останніх досліджень і публікацій. Сутність надання експортних кредитів (позик) як засобу регулювання експорту у світі представлена в дослідженнях Я. Белінської [7], І. Іванової [3], М. Ковальчук-Швецової [4], О. Юхти [20] та інших науковців. Кожне з них $\epsilon$ самостійним напрацюванням, яке охоплює загальні аспекти кредитування експорту, що залишає місце для дискусій щодо конкретних його частин та можливості їх повноцінного застосування надалі.

Формулювання цілей статті. Метою статті є оцінювання особливостей кредитування експорту в різних країнах світу, можливості використання досвіду щодо надання експортних кредитів одних держав для інших.

Виклад основного матеріалу. Відповідно до Закону України «Про забезпечення масштабної експансії експорту товарів (робіт, послуг) українського походження шляхом страхування, гарантування та здешевлення кредитування експорту» [1] експортний кредит є наданням позики банком або імпортеру для придбання товарів та послуг експортера, або експортеру задля забезпечення продажу продукції, тому кредитування експорту є процесом надання експортних кредитів. Згідно з одним зі звітів про Експортне заохочення і COT потреба кредитування експорту з'являється тоді, коли «покупцеві чи постачальнику експортованих товарів чи послуг дозволено відстрочити оплату [за продукцію]» [2].

Наприклад, I. Іванова [3, с. 53] експортні кредити (далі - ЕК) відносить до засобу підтримки державою експорту за допомогою певних установ державного чи приватного типу, тобто банків та експортно-кредитних агентств (далі - ЕКА), а М. Ковальчук-Швецова $[4$, c. 613,614$]$ - до методів фінансування експорту для його стимулювання. На наш погляд, ЕК є засобом прямого фінансування експорту, що діє на сам його процес та опосередковується як банками, так й ЕКА.

Доцільно відзначити, що надаються коротко- (до 2-х років), середньо- (2-5 років) та довгострокові (більше 5 років) ЕК державними та/або комерційними банками загалом [2]. Також може відбуватися покриття ЕК за ризиками їх несплати через гарантування, тобто зобов'язання виплатити кредитору позику гарантом, яким виступає, як правило, ЕКА. Крім того, разом 3 експортними гарантіями (далі - ЕГ) за такими кредитами діє їх страхування ЕКА перед кредитором [1]. Це пов'язане з можливістю несплати експортного кредиту. Цікаво, що ролі кредиторів, гарантів і страховиків можуть змінюватися та поєднуватися. 
ЕК разом із послугами ЕГ та страхування надаються після заяви позичальника та через розгляд ризиків щодо допустимості їх прийняття, до яких можна віднести ймовірне банкрутство позичальника, втрату ним доходів тощо. Такі ризики по країнах можуть розраховуватися, згідно з Угодою щодо офіційної підтримки експортного кредитування [5], за рангами від «0» до «7» за зростанням. Відповідно до тієї ж Угоди [5] установлено мінімальні ставки експортних кредитів, а саме CIRR, що віддзеркалюють витрати надання ЕК всередині країни та відповідають ставці, яка є прийнятною позичальнику залежно від оцінювання розвитку та кредитних ризиків. CIRR для валюти країни вибирається на основі прибутковості облігацій державного типу від 3 до 8,5 років [5].

Якщо розглядати ЕК в країнах світу, то у Великобританії вони надаються комерційними банками здебільшого імпортерам. В країні переважають середньой довгострокові кредити, вартість яких за 2008-2018 pр. знизилась із 2700,00 до 2400,00 млн. дол. США за даними Експортно-імпортного банку Сполучених Штатів Америки [6].

Крім комерційних банків, ще одним важливим учасником кредитування експорту у Великобританії $€$ "UK Export Finance" як ЕКА, що є складовою Уряду Сполученого Королівства й державною установою, що має свій дохід, який формується на основі котирування бондів, тобто облігацій [7, с. 126]. Щороку [7, с. 126] "UK Finance" витрачає близько 390,00 млн. дол. США за крос-курсом НБУ [8] на підтримку процентної ставки по кредитах, яка складає близько $0,75 \%$ від їх суми. Згідно зі щорічним звітом ЕКА Великобританії [9] у 2017-2018 фінансовому році "UK Finance” здійснило фінансову підтримку експортерів й надало кредитів, гарантій і страхових послуг на суму 3257,90 млн. дол. США за крос-курсом [8], що враховується надалі в пропорції 57:6:37\%. "UK Finance” [9] працювало із 76 державами й 191 компанією, зокрема з Україною, імпортерам якої було надано страхових послуг на суму 1,10 млн. дол. США у тому ж фінансовому році.

Дещо іншим є кредитування експорту у Німеччині (далі - ФРН), що надається, як правило, Експортним кредитним банком ФРН [10]. ЕК надаються за ставкою до 0,25\% від їх суми за гарантування ЕКА “Euler Hermes”, завдяки якому експорт збільшився приблизно на 15\% [11], згідно з джерелом [10]. Обсяг ЕК для експортера чи імпортера обчислюється на основі угоди й для імпортера не має бути більшим за $85 \%$ такої угоди й 93,73 млн. дол. США за крос-курсом [8] за даними [10] з терміном погашення у чотири роки.

Варто відзначити, що за 2008-2018 роки вартість середньо- й довгострокових ЕК у ФРН зросла на 11,11\% до 12000 млн. дол. США [6]. Також обсяг короткострокових ЕК і коштів, наданих на певні програми в контексті підтримки експорту споживчих товарів, впав до 11060 млн. дол. США, або на 7,83\% [6]. Щодо гарантування ЕК, то інформація Федерального міністерства фінансів [12] свідчить про те, що їх вартість у млн. дол. США зросла із 173510,15 до 174 892,10 за крос-курсом [8].

Щодо ЕК у Франції, то можна стверджувати, що їх дають близько двадцяти комерційних банків за ставками, що нижче за 5\%, згідно із сайтом підтримки місцевого експорту [13], через контроль з боку Міністерства економіки і фінансів Франції [7, с. 122]. Банки вибирають позичальника, а держава, незважаючи на обмеження, фінансує витрати за пільгою з відсоткових ставок [7, с. 122-123]. Крім того, з 2015 р. діє рефінансування (викуп в кредитора) ЕК для підтримки місцевого бізнесу за грантами Державним банком Франції SFIL, що акумулює доходи через випуск облігацій, у 95\% наданої вартості [13]. Це присутнє, наприклад, у побудові для продажу за кордон новітніх кораблів на суму 1443 млн. дол. США [13].

У Франції переважають середньо- й довгострокові ЕК, що за 2008-2018 рр. зросли з 8600 до 8900 млн. дол. США, тобто на 3,49\%, хоча з 2009 р. вони знизилися практично вдвічі [6].

На нашу думку, варто приділити увагу досвіду надання ЕК у Польщі, де ЕК спрямовані на певну продукцію. Їх основою є державна програма «Фінансова підтримка експорту» [14], що містить підтримку імпортерів як через партнерство, так і через оцінювання ризиків [15]. ЕК у Польщі даються Господарським банком (BGK) разом із можливим їх страхуванням Експортною кредитною та страховою державною корпорацією “KUKE S.A.” як на короткостроковий, так i на довгостроковий періоди (до 15 років) [14; 15].

Найбільш поширеним видом ЕК в Польщі $є$ кредит на купівлю споживчих товарів у злотих, євро та доларах США. Його вартість складається 3 позики, витрат на страхування, обслуговування, комісію сплати дебіторської заборгованості та щоквартальну комісію, розмір яких залежить від валюти, де менші витрати детерміновані ii вищою вартістю [15]. Наприклад, для України як імпортера вони становлять 2,05-2,34\% вартості кредиту для валюти «євро» (1,50-1,77\% складають щорічні витрати на кредит і страхування; 0,20\% - комісія з оплати дебіторської заборгованості, 0,35-0,37\% щоквартальна комісія) [15].

Також поширеним ЕК у Польщі $є$ капітальний кредит на експорт обладнання, що дається більше за два роки до 85\% вартості товарів, що експортуються, але не менше за 1 млн. євро [15]. Вартість такого ЕК, наприклад, для річного періоду виплат i погашення у п'ять років складає для України 7,81-11,55\% для євро [15].

Досить розвиненим є кредитування експорту в Китаї (далі - КНР). В цій країні надання ЕК представлено Експортно-імпортним банком Китаю під ставку, що не є більшою за 4,00\% [16]. Цей банк дає такі основні види кредитів [16], як кредити експортерам та імпортерам, імпортні кредити підприємствам КНР. Наприклад, ЕК експортерам даються в національній та іноземній валюті для підтримки високотехнологічної (ЧСЕ) та низько технологічної продукції на умо- 
вах Експортно-імпортного банку, а окремо - на суднову галузь [16].

Щодо вартості ЕК, то в КНР за 2008-2018 рр. середньо- й довгострокові кредити підвищилися 3 24000 до 39100 млн. дол. США, а короткострокові кредити й кошти на експортні програми зросли 3 375200 до 481400 млн. дол. США з 2016 по 2018 рр. [6]. Близько 53\% кредитів спрямовані на імпорт, а 47\% - на експорт [16].

Невід'ємною складовою ЕК у КНР є страхування, що здійснюється державною Китайською експортною та кредитною страховою корпорацією (SINOSURE) [17]. Роздільно страхуються коротко-, середньо- й довгострокові кредити до 90,00\% вартості через оцінювання ризиків на основі даних про понад 40 тис. банків, 800 галузей та 10 млн. підприємств [17]. ЕКА КНР на кінець 2018 р. застрахувало ЕК на 12700 млн. дол. США [17].

Відповідно до наших аналітичних досліджень кредитування експорту чинить вагомий вплив на сам експорт. За 2008-2017 рр. одновідсоткове збільшення середньо- та довгострокових кредитів у КНР на 240 млн. дол. США стало причиною зростання експорту на 1,11\%, або на 15 880,66 млн. дол. США, за розрахунками по MS EXCEL згідно з даними джерела [6] й Національного бюро статистики КНР [18].

Щодо України, то варто зазначити, що кредитування експорту в нашій державі не є досить розвиненим. Незважаючи на присутність його певних програм $і$ характеристик, наприклад в «УКРЕКСІМБАНКу» [19], щодо кредитів для імпортерів на придбання певної техніки за ставками 6,00-19,00\% залежно від валюти, все ж таки наявні проблеми кредитування експортерів, що пов'язані з гарантіями та страхуванням ЕК.

Створення ЕКА в Україні у 2018 р., згідно з джерелом [1] та дослідження О. Юхти [20, с. 78-80], не дає значного ефекту під час їх вирішення, що супроводжене відсутністю сформованості нормативно-правової бази та пріоритетів функціонування. Ми погоджуємося 3 думкою О. Юхти [20, с. 80] про те, що вітчизняне ЕКА для поповнення своїх ресурсів має діяти на зовнішньому ринку й взаємодіяти 3 місцевими органами влади в умовах децентралізації, а не лише з Кабінетом Міністрів України. Крім того, на наш погляд, надання ЕК в Україні та їх покриття на початковому етапі мають здійснюватися 3 пріоритетом на певні експортні товари, як в Польщі та Франції, а не на підприємства й бізнес загалом, що дасть змогу реалізувати наявні переваги в торгівлі, зокрема ресурси. Не потрібно боятися реалізовувати експорт щодо сільського господарства, як у КНР, адже доцільно спочатку сформувати систему повноцінного його кредитування.

Висновки. За результатами проведеного дослідження оцінено особливості кредитування експорту в певних державах. Виявлено, що надання ЕК супроводжується їх покриттям щодо гарантування й страхування як із боку держави, так і через приватний сектор. Визначено різні орієнтації кредитування експорту в контексті експортерів, імпортерів та певних продуктів. Виокремлено загальну тенденцію до зростання розміру ЕК через їх вагому роль у розвитку експорту. Зроблено припущення про доцільність розвитку кредитування експорту в Україні щодо вектору продажів визначених товарів за кордон.

\section{Список літератури:}

1. Про забезпечення масштабної експансії експорту товарів (робіт, послуг) українського походження шляхом страхування, гарантування та здешевлення кредитування експорту : Закон України від 20 грудня 2016 р. № 1792 -VIII. База даних «Законодавство України» / ВР України. URL: https://zakon.rada.gov.ua/laws/show/1792-19 (дата звернення: 18.09.2019).

2. Export promotion and the WTO. A brief guide (n. d.). URL: http://ierc.bia-bg.com/uploads/links/files/links_1dd0d2 1d91f8b61f6f720ee2d08b0b58.pdf (дата звернення: 18.09.2019).

3. Іванова I. Державна підтримка експорту як інструмент захисту національних інтересів: досвід СС, СОТ та уроки для України. Стратегічні пріоритети. 2015. № 1 (34). С. 51-55.

4. Ковальчук-Швецова М. Основні форми та методи стимулювання експорту продукції машинобудівних підприємств. Видавництво Львівської політехніки. 2010. № 690. С. 612-617.

5. Arrangement on officially supported export credit. 2018. URL: http://www.oecd.org/officialdocuments/publicdisplay documentpdf/?cote=TAD/PG(2018)1\&docLanguage=En (дата звернення: 18.09.2019).

6. Export-import bank of the United States (n. d.). URL: https://www.exim.gov (дата звернення: 19.09.2019).

7. Белінська Я. Державна підтримка експорту: зарубіжний досвід та уроки для України. Стратегічні пріоритети. 2008. № 3 (8). С. 120-131.

8. Офіційний курс гривні щодо іноземних валют (н. д.). URL: https://bank.gov.ua/markets/exchangerates/?date=19. 09.2019\&period=monthly (дата звернення: 19.09.2019).

9. UK Export Finance Annual Report and Accounts 2017-2018 (n. d.). URL: https://assets.publishing.service.gov.uk/ government/uploads/system/uploads/attachment_data/file/718043/ukef-annual-report-2017-to-2018.pdf (дата звернення: 19.09.2019).

10. AKA European Export + Trade Bank (n. d.). URL: https://www.akabank.de/en (дата звернення: 19.09.2019).

11. Euler Hermes Global (n. d.). URL: https://www.eulerhermes.com/en_global.html (дата звернення: 19.09.2019).

12. Federal Ministry of Finance (n. d.). URL: https://www.bundesfinanzministerium.de/Web/EN/Home/home.html (дата звернення: 19.09.2019).

13. SFIL. Supporting local investment and export (n. d.). URL: https://sfil.fr/en (дата звернення: 19.09.2019). 
14. Export Credits (n. d.). URL: https://www.gov.pl/web/finance/export-credits-financial-export-support (дата звернення: 19.09.2019).

15. Financial Support for Polish Companies: Export and Expansion. 2017. URL: https://www.en.bgk.pl/files/public/Pliki/ Przedsiebiorstwa/wsparcie_eksportu/BGK_Financial_Support_for_Polish_Comanies_-_Export_and_Expansion.pdf (дата звернення: 19.09.2019).

16. The Export-Import Bank Of China (n. d.). URL: http://english.eximbank.gov.cn/Business/index.html\#ourBusinessхwу-1 (дата звернення: 19.09.2019).

17. China export \& credit insurance corporation (n. d.). URL: http://www.sinosure.com.cn/en/index.shtml (дата звернення: 19.09.2019).

18. National Bureau of Statistics of China (n. d.). URL: http://www.stats.gov.cn/english (дата звернення: 19.09.2019).

19. Ukreximbank (n. d.). URL: https://www.eximb.com (дата звернення: 19.09.2019).

20. Юхта О. Експортно-кредитне агентство як ефективний інститут організації фінансово-кредитної підтримки експортерів. Інвестиції: практика та досвід. 2019. № 11. С. 76-81.

\section{References:}

1. Pro zabezpechennia masshtabnoi ekspansii eksportu tovariv (robit, posluh) ukrainskoho pokhodzhennia shliakhom strakhuvannia, harantuvannia ta zdeshevlennia kredytuvannia eksportu : Zakon Ukrainy vid 20.12.2016 r. No. 1792-VIII [Law of Ukraine "On Ensuring Large-Scale Export Goods (Works, Services) Expansion of Ukrainian Origin Through Insurance, Guarantee and Cheaper Export Crediting”]. Available at: https://zakon.rada.gov.ua/laws/show/1792-19 (accessed: 18 September 2019).

2. Export promotion and the WTO (n. d.), a brief guide. Available at: http://ierc.bia-bg.com/uploads/links/files/links _ 1 dd0d21d91f8b61f6f720ee2d08b0b58.pdf (accessed: 18 September 2019).

3. Ivanova I. (2015). Derzhavna pidtrymka eksportu yak instrument zakhystu natsionalnykh interesiv: dosvid YeS, SOT ta uroky dlia Ukrainy [A State Export Support as a Tool for Protecting National Interests: Experience of the EU and WTO and Lessons For Ukraine]. Strategichni priory’tety [Strategic Priorities], 1 (34), 51-55 [in Ukrainian].

4. Kovalchuk-Shvetsova M. (2010).Osnovni formy ta metody stymuliuvannia eksportu produktsii mashynobudivnykh pidpryiemstv [Main Forms and Methods of Stimulating the Export Products of Machine-Building Enterprises]. Vydavnytstvo Lvivskoi politekhniky [Lviv Polytechnic Publishers], 690, 612-617 [in Ukrainian].

5. Arrangement on officially supported export credit (2018). Available at: http://www.oecd.org/officialdocuments/public displaydocumentpdf/?cote=TAD/PG(2018)1\&docLanguage=En (accessed: 18 September 2019).

6. Export-import bank of the United States (n. d.). Available at: https://www.exim.gov (accessed: 19 September 2019).

7. Belinska Ya. (2008). Derzhavna pidtrymka eksportu: zarubizhnyi dosvid ta uroky dlia Ukrainy [State Support for Exports: Foreign Experience and Lessons for Ukraine]. Stratehichni priorytety [Strategic Priorities], 3 (8), 120-131 [in Ukrainian].

8. Ofitsiinyi kurs hryvni shchodo inozemnykh valiut [Official Exchange Rate of Hryvnia Against Foreign Currencies] (n. d.). Available at: https://bank.gov.ua/markets/exchangerates/?date=19.09.2019\&period=monthly (accessed: 19 September 2019).

9. UK Export Finance Annual Report and Accounts 2017-18 (n. d.). Available at: https://assets.publishing.service. gov.uk/government/uploads/system/uploads/attachment_data/file/718043/ukef-annual-report-2017-to-2018.pdf (accessed: 19 September 2019).

10. AKA European Export + Trade Bank (n. d.). Available at: https://www.akabank.de/en (accessed: 19 September 2019).

11. Euler Hermes Global (n. d.). Available at: https://www.eulerhermes.com/en_global.html (accessed: 19 September 2019).

12. Federal Ministry of Finance (n. d.). Available at: https://www.bundesfinanzministerium.de/Web/EN/Home/home.html (accessed: 19 September 2019).

13. SFIL (n. d.). Supporting local investment and export. Available at: https://sfil.fr/en (accessed: 19 September 2019).

14. Export Credits (n. d.). Available at: https://www.gov.pl/web/finance/export-credits-financial-export-support (accessed: 19 September 2019).

15. Financial Support for Polish Companies: Export and Expansion (2017). Available at: https://www.en.bgk.pl/files/public/ Pliki/Przedsiebiorstwa/wsparcie_eksportu/BGK_Financial_Support_for_Polish_Comanies_-_Export_and_Expansion.pdf (accessed: 19 September 2019).

16. The Export-Import Bank Of China (n. d.). Available at: http://english.eximbank.gov.cn/Business/index. html\#ourBusiness-Xwy-1 (accessed: 19 September 2019).

17. China Export \& Credit Insurance Corporation (n. d.). Available at: http://www.sinosure.com.cn/en/index.shtml (accessed: 19 September 2019).

18. National Bureau of Statistics of China (n. d.). Available at: http://www.stats.gov.cn/english (accessed: 19 September 2019).

19. Ukreximbank (n. d.). Available at: https://www.eximb.com (accessed: 19 September 2019).

20. Yukhta O. (2019). Eksportno-kredytne ahentstvo yak efektyvnyi instytut orhanizatsii finansovo-kredytnoi pidtrymky eksporteriv [Export-Credit Agency as an Effective Institute of Organization of Financial-Credit Support of Exporters]. Investytsii: praktyka ta dosvid [Investments: Practice and Experience], 11, 76-81 [in Ukrainian]. 


\section{КРЕДИТОВАНИЕ ЭКСПОРТА КАК СРЕДСТВО ЕГО ФУНКЦИОНИРОВАНИЯ}

В статье рассмотрены особенности кредитование экспорта в некоторых странах мира. Определено, что оно направлено непосредственно на стимулирование его развития касательно как обеспечения оборота продукиии, так и средств от ее продажи. Доказано, что кредитование экспорта опосредованно не только государственной поддержкой, но и предпринимательской деятельностью. Отражено, что порядок предоставление экспортных кредитов сопровождается их гарантированием и страхованием через оиенивание рисков потерь политического и коммерческого характера за определенную плату на основе правил Организации экономического сотрудничества и развития. Аналитически проиллюстрирована имеющаяся зависимость кредитования экспорта от его стоимости. Оиенены возможные дальнейшие перспективы развития предоставления экспортных кредитов в Украине на основе учета опьта и оценивания экономической конъюнктуры.

Ключевые слова: экспорт, экспортные гарантии, экспортные кредиты, экспортно-кредитное агентство, страхование экспорта.

\section{EXPORT LENDING AS A MEANS OF ITS FUNCTIONING}

The article discusses about the features of the export lending development in some countries of the world. It is proved the export lending as a phenomenon is one of a main form of the direct export financing in the market. It is noted the lending is a big support for the turnover of export goods and revenues from their sell abroad, so it is an important part of whole economics, especially in this current conditions of cyclicality and instability. It is determined the lending consists of two basic parts. The first part includes short, medium-and long-term export credits in some similar and different forms. The second part adds in an export cover. As well the export cover including multiform export guarantees and the export insurance. It is specified the export credits, export guarantees and the export insurance is possible while certain risks could be taken. It is noted the risks are identified on a certain number scale, which reflecting the possibility or impossibility of risk covering. Based on the assessment of export credits'features in some countries identified the important role of state and commercial banks in their provision. Also the huge value of export credit agencies in the export cover assessed. Center on the study of individual export lending's subjects the general role of the state as a special institute in its course is shown. According to some analytical statistical data, the trend of export credit development in the world is determined. Except time, two types and two subtypes export credits are highlighted. Based on the comparison of the export lending in some countries of the world identified the advantage of certain export credits' types in some world regions, such as Western and Central Europe and Asia. The possibility of applying the countries' experience under consideration in other world's countries to improve the export lending to them is shown. It is noted the experience is not complex, only partial, and related to the vector of the export lending development, which could be dynamic due to its reaction to the current processes of market economy in a particular state of the world.

Key words: export, export guarantees, export credits, export credit agency, export insurance. 